\title{
Biogenesis of Silver Nanoparticles Feasible for Industrial Application Using Yeast-fungi Secreted Enzymes and Proteins
}

\author{
Asem A. Mohamed ${ }^{1}$, M.K. Zahran'2, M.H. El-Rafie ${ }^{3}$ \\ ${ }^{1}$ Chemistry of Natural and Microbial Products Department, National Research Center, Cairo, Egypt. \\ ${ }^{2}$ Department of Chemistry, Faculty of Science, Helwan University, Cairo, Egypt. \\ ${ }^{3}$ Textile Research Division, National Research Center, Cairo, Egypt.
}

\begin{abstract}
ACCHAROMYCES cerevisiae, Rhodotorula glutinis and Geotrichum candidum were selected for biosgenesis of silver nanoparticles (AgNPs) using yeast reductases. Extracellular proteins act as stabilizers for so formed AgNPs. Factors affecting biosynthesis; biomass concentration, $\mathrm{AgNO}_{3}$ concentration and the ratio of $\mathrm{AgNO}_{3}$ : to biomass concentration on. The Optimum conditions for biosynthesis of AgNPs could be attained using biomass of Saccharomyces cerevisiae ( $3 \mathrm{~mL} / 100 \mathrm{~mL}): .9 \mathrm{mM} \mathrm{AgNO}_{3}: \mathrm{pH} 12: 25{ }^{\circ} \mathrm{C}$ and $24 \mathrm{~h}$ incubation). Under these conditions, the maximum concentration of well stabilized AgNPs obtained was $900 \mathrm{ppm}$ with a mean diameter range of $1.5-12 \mathrm{~nm}$. Such solution is unequivocally feasible for industrial applications.
\end{abstract}

Keywords: Silver nano particles, Yeast fungi, Reductase enzymes, Optimization, Textile treatment.

\section{Introduction}

The nano-scale silver will play roles in understanding and ability to manipulate biological processes which will be the central theme to present biomedical and biological issues that need a nanoscience or nanotechnology approach[1]. The extremely small size of nano-particles relative to their volume allows them to easily interact with other particles and increases their antibacterial efficiency[2].

Metal nanoparticles of desired size and shape have been obtained successfully using living organisms from simple unicellular organisms to highly complex eukaryotes. Several microorganisms have been found to be capable of synthesizing intra and/or extra cellular inorganic nanocomposites[3].

Prokaryotes as nanoparticle synthesizers, can be easily modified using genetic engineering techniques for over expression of specific enzymes, apart from the ease of handling. The use of eukaryotes, especially fungi, is potentially exciting since they secrete copious amounts of proteins, thus increasing productivity, and their easy usage in laboratory works is a suitable option in production of metallic nanoparticles among other microorganisms [4-8]. Moreover, the process can be easily scaled up, economically viable with the possibility of easily covering large surface areas by manipulation of growth parameters[9].

Biogenesis of metal nanoparticles depended on the type and behavior of microorganism. Researchers have been working on extracellular biosynthesis of metal nanoparticles by bacteria, actinomycetes, yeast, fungi and other biological sources[10].

Several methods could be used to optimize biotechnological processes in the advance of bioprocess engineering [11-13]. Methodology is a collection of techniques that are developed to find out optimal conditions of input factors which maximize/minimize the output variables $[14,15]$.

The aim of recent study is to determine factors affecting biogenesis of silver nanoparticles (AgNPs) by Saccharomyces cerevisiae (Baker's yeast), Rhodotorula glutinis and Geotrichum candidum, to obtain the optimum conditions for the preparation of AgNPs solution feasible for industrial application such as biomass concentration, $\mathrm{AgNO}_{3}$ concentration and the ratio of $\mathrm{AgNO}_{3}$ to biomass concentration on the production of AgNPs.

*Corresponding author e-mail:aalfarouk@yahoo.com 


\section{Materials and Method}

Microorganism and culture conditions

Saccharomyces cerevisiae (Baker's yeast), Rhodotorula glutinis.and Geotrichum candidum. used in this study were obtained from_Regional Center for Mycology and Biotechnology, ALAzhar University, Nasr city, Cairo.. strains were Test maintained at $30^{\circ} \mathrm{C}$ on Czapek Dox Agar.

\section{Culture media}

Czapek Dox Agar medium (CDA) (Maintenance medium)

Maintenance medium is composed of $(\mathrm{g} / \mathrm{L})$ : sodium nitrate 2 , magnesium sulfate 0.5 , potassium chloride 0.5 , potassium dihydrogen phosphate 1 , ferrous sulfate 0.1 , sucrose 20 and agar 20. $\mathrm{pH}$ was adjusted at 6.5-7.

\section{Fermentation media}

The fermentation medium was Czapek Dox medium devoid of agar. $\mathrm{pH}$ was adjusted to be 6.5-7. Ingredients were dissolved in fresh distilled water, and applied to $250 \mathrm{~mL}$ Erlenmeyer conical flasks each containing $50 \mathrm{~mL}$, then sterilized at $121^{\circ} \mathrm{C}$ for $20 \mathrm{~min}$.

\section{Fermentation process}

Inoculation was performed by $2 \mathrm{~mL}$ of 7 days old vegetative growth in two replicates of $250 \mathrm{~mL}$ Erlenmeyer conical flasks containing $50 \mathrm{~mL}$ of the fermentation medium. Incubation was done on a shaker incubator at $30 \pm 2{ }^{\circ} \mathrm{C}$ and $150-200$ rpm. First and second samples were removed after $72 \mathrm{hr}$ and $96 \mathrm{hr}$, respectively, for the bio- synthesis of silver nanoparticles.

\section{Preparation of silver nanoparticles}

After fermentation process the biomass was recovered by decantation-centrifugation and washed extensively with fresh distilled water. The harvested biomass then re-suspended in $100 \mathrm{~mL}$ fresh distilled water at $\mathrm{pH} 12.0 .1 \mathrm{~m} \mathrm{~mol}$ of silver nitrate was added in the presence of cells. After 30 min, the solution was filtered to remove cells then subjected to U.V-Vis spectrophotometer after 24 hr. Reduction of metal ions was detected by visual inspection of the solution, as well as, by UV-Vis spectra, and transmission electron microscopy (TEM).

As a farther step, the colloidal solution formed was checked for the presence of excess silver ion $\left(\mathrm{Ag}^{+}\right)$using dilute $\mathrm{NaCl}$ solution, in order to be sure of complete reduction. When no white precipitate is observed, this means the complete transformation of $\left(\mathrm{Ag}^{+}\right)$to $\left(\mathrm{Ag}^{\circ}\right)$.

\section{Characterization of silver nano-particles}

Ultra violet-visible (UV-Vis) spectra

Ultra violet-visible (UV-Vis) spectra have been proved to be quite sensitive to the formation of silver colloids because silver nanoparticles exhibit an intense absorption peak due to the surface plasmon excitation (it describes the collective excitation of condition electrons in a metal). Silver nanoparticles were recorded by. spectrophotometer from 300 to $700 \mathrm{~nm}$. The filtrate without adding silver nitrate was used as a blank.

Transmission Electron Microscope (TEM)

Particle size and shape were detected by JEOLJEM-1200. Specimens for TEM measurements were prepared by dissolving a drop of colloid solution on a 400 mesh copper grid coated by an amorphous carbon film and evaporating the solvent in air at room temperature. The average diameter of the silver nanoparticles was determined from the diameter of 100 nanoparticles found in several arbitrarities chosen areas in enlarged microphotographs.

\section{$\underline{\text { Results and Discussion }}$}

Current study attempts to achieve well stabilized AgNPs colloidal solution with higher concentration feasible for industrial applications. This, indeed, was done through investigations into biomass concentration, $\mathrm{AgNO}_{3}$ concentration, and ratio of $\mathrm{AgNO}_{3}$ to biomass concentration as detailed under.

\section{Investigations into biomass concentration. \\ Geotrichum candidum}

Biomass suspension produced from $0.5,1.0$ and $2.0 \mathrm{~mL}$ of vegetative growth of Geotrichum candidum as inoculum size were exposed to 0.1 $\mathrm{mM} \mathrm{AgNO}_{3}$ for $72 \mathrm{hr}$.

Figure 1, showed the effect of biomass concentration on stability of biogenic nano-silver produced by Geotrichum candidum. $\mathrm{pH}$ of solutions was adjusted to $8,10,11$ and 12 followed by addition of $0.1 \mathrm{mM} \mathrm{AgNO}$. Vessels were kept for 30 minutes, then cells were removed from the reaction medium. Vessels were kept under ambient conditions $\sim 25^{\circ} \mathrm{C}$ for $24 \mathrm{hr}$.

Data presented in Fig. 1 indicated the extreme stability of $\mathrm{Ag}^{\mathrm{o}}$ nanoparticles produced by using biomass concentration $1.0 \mathrm{~mL}$.

Rhodotorula glutinis

Biomass suspension produced from 0.5 $\mathrm{mL}, 1 \mathrm{~mL}$, and $2 \mathrm{~mL}$ of vegetative growth of 
Rhodotorula glutinis were incubated on a shaker incubator at $30 \pm 2{ }^{\circ} \mathrm{C}$ at $150 \mathrm{rpm}$ for $72 \mathrm{hr}$ to 0.1 $\mathrm{mM} \mathrm{AgNO}_{3}$ respectively for $24 \mathrm{hr}$.

Figure 2, shows the effect of biomass concentration on stability of biogenic nano-silver upon exposure of $100 \mathrm{~mL}$ of biomass suspension produced from $0.5 \mathrm{~mL}, 1 \mathrm{~mL}$, and $2 \mathrm{~mL}$ inoculum of Rhodotorula glutinis incubated on a shaker incubator at $30 \pm 2{ }^{\circ} \mathrm{C}$ at $150 \mathrm{rpm}$ for $72 \mathrm{hr}$ to 0.1 $\mathrm{mM} \mathrm{AgNO}_{3}$ respectively for $24 \mathrm{hr}$.

Figure 2, indicated the extreme stability of the $\mathrm{Ag}^{\mathrm{o}}$ nanoparticles attained at using the biomass concentration of $1 \mathrm{~mL}$.

\section{Saccharomyces cerevisiae}

Biomass suspension produced from $0.5 \mathrm{~mL}, 1 \mathrm{~mL}$, and $2 \mathrm{~mL}$ of vegetative cells of Saccharomyces cerevisiae were incubated on a shaker incubator at $30 \pm 2{ }^{\circ} \mathrm{C}$ at $150 \mathrm{rpm}$ for $72 \mathrm{hr}$ to $0.1 \mathrm{mM} \mathrm{AgNO}_{3}$ respectively for $24 \mathrm{hr}$.

Figure 3, shows the effect of the biomass concentration on stability of silver nanoparticles. $\mathrm{pH}$ of the biomass solution was adjusted to 8,10,11 and 12 using diluted solutions of $\mathrm{NaOH}(0.1 \mathrm{~N})$ followed by addition of $0.1 \mathrm{mM}$ of $\mathrm{AgNO}_{3}$. Vessels were kept for
30 minutes, then cells were removed from the reaction medium. Vessels were kept under ambient conditions $\sim 25^{\circ} \mathrm{C}$ for $24 \mathrm{hr}$.

Data presented in Fig. 3 indicated the extreme stability of the $\mathrm{Ag}^{\mathrm{O}}$ nanoparticles attained upon using biomass concentration of $1.0 \mathrm{~mL}$.

Effect of silver nitrate concentration on biosynthesis of silver nanoparticles

\section{Geotrichum candidum}

The effect of silver nitrate concentration on bio-synthesis of silver nanoparticles was studied by exposing biomass suspension produced from $1 \mathrm{~mL}$ of Geotrichum candidum inoculation size incubated on a shaker incubator at $30 \pm 2{ }^{\circ} \mathrm{C}$ at $150 \mathrm{rpm}$ for $72 \mathrm{hr}$ to $0.1,0.2,0.3$, and $0.4 \mathrm{mM}$ of $\mathrm{AgNO}_{3}$ respectively for $24 \mathrm{hr}$.

Figure 4, represents the U.V-Vis spectra for the AgNps solution prepared by Geotrichum candidum by variation of silver nitrate concentration to $0.1,0.2,0.3$, and $0.4 \mathrm{mM}$ of $\mathrm{AgNO}_{3}$ respectively.

Figure 4, indicated that the best results obtained for silver nanoparticles bio-synthesis was by using $0.3 \mathrm{mM}$ of $\mathrm{AgNO}_{3}$.

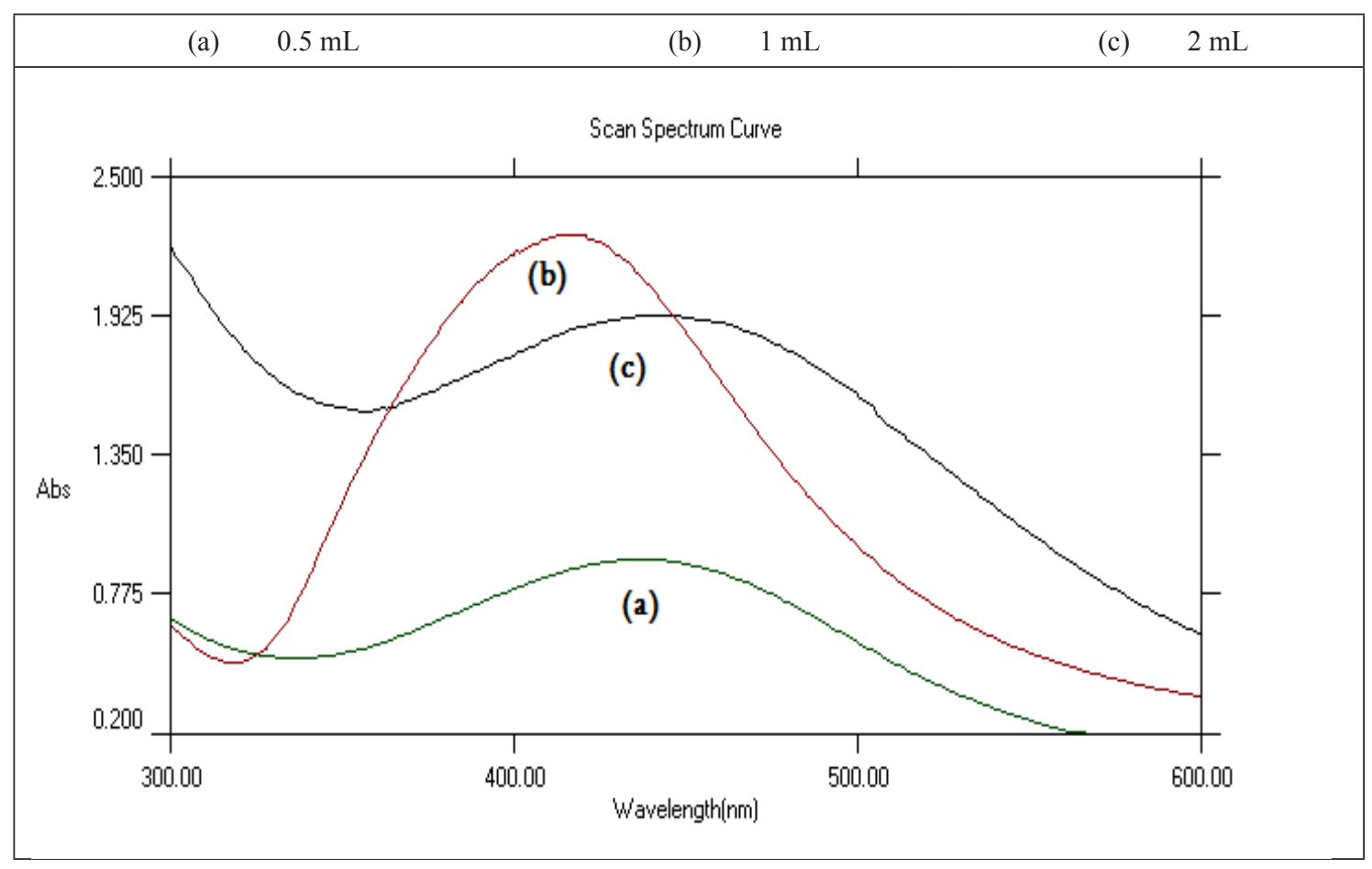

Fig. 1. UV-Vis spectra recorded as a function of biomass concentration of Geotrichum candidum after $72 \mathrm{hr}$ incubation. 


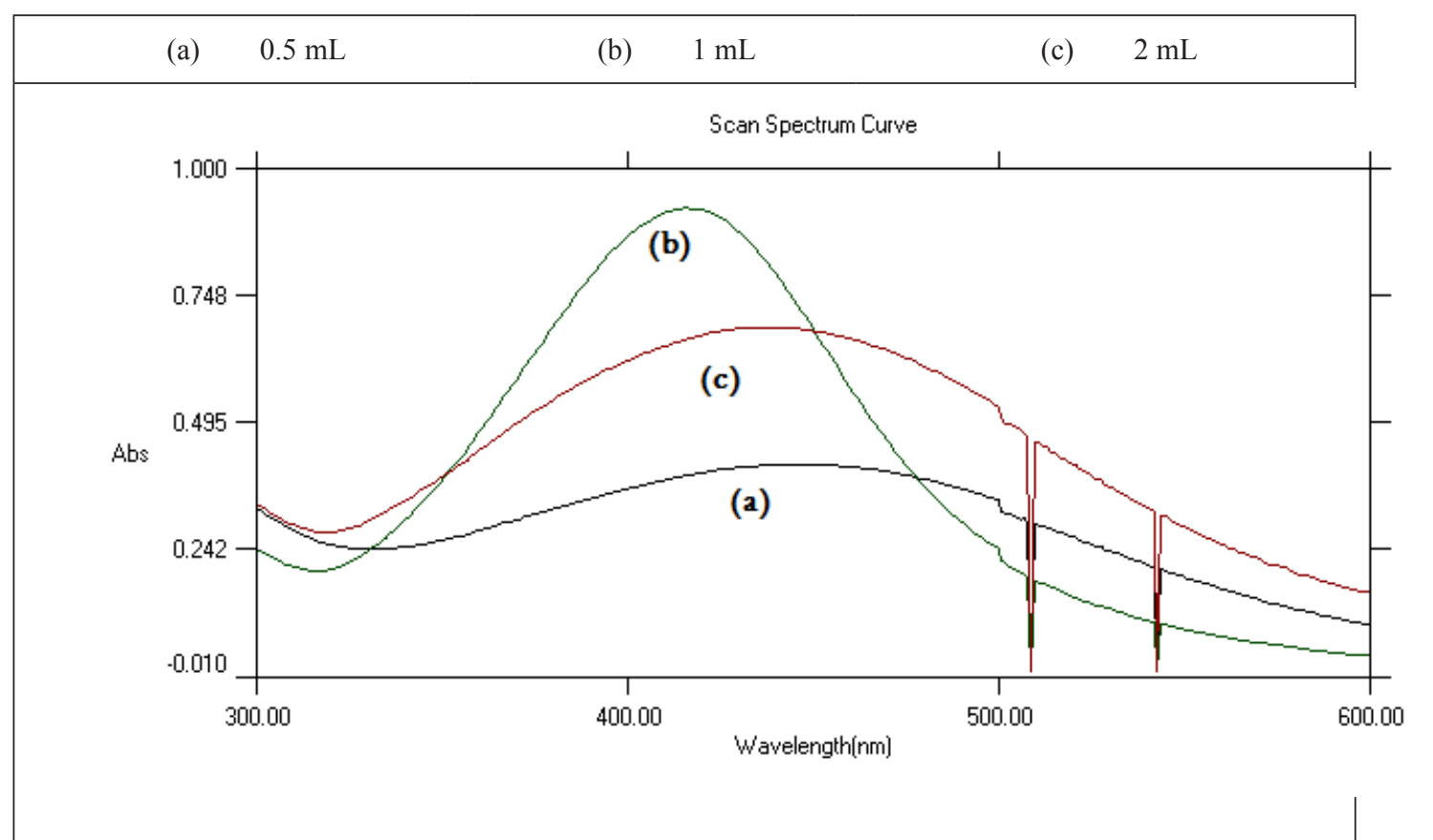

Fig. 2. UV-Vis spectra recorded as a function of biomass concentration of Rhodotorula glutinis after 72 hr incubation.

(a) $\quad 0.5 \mathrm{~mL}$

(b)

Scan Spectrum Curve

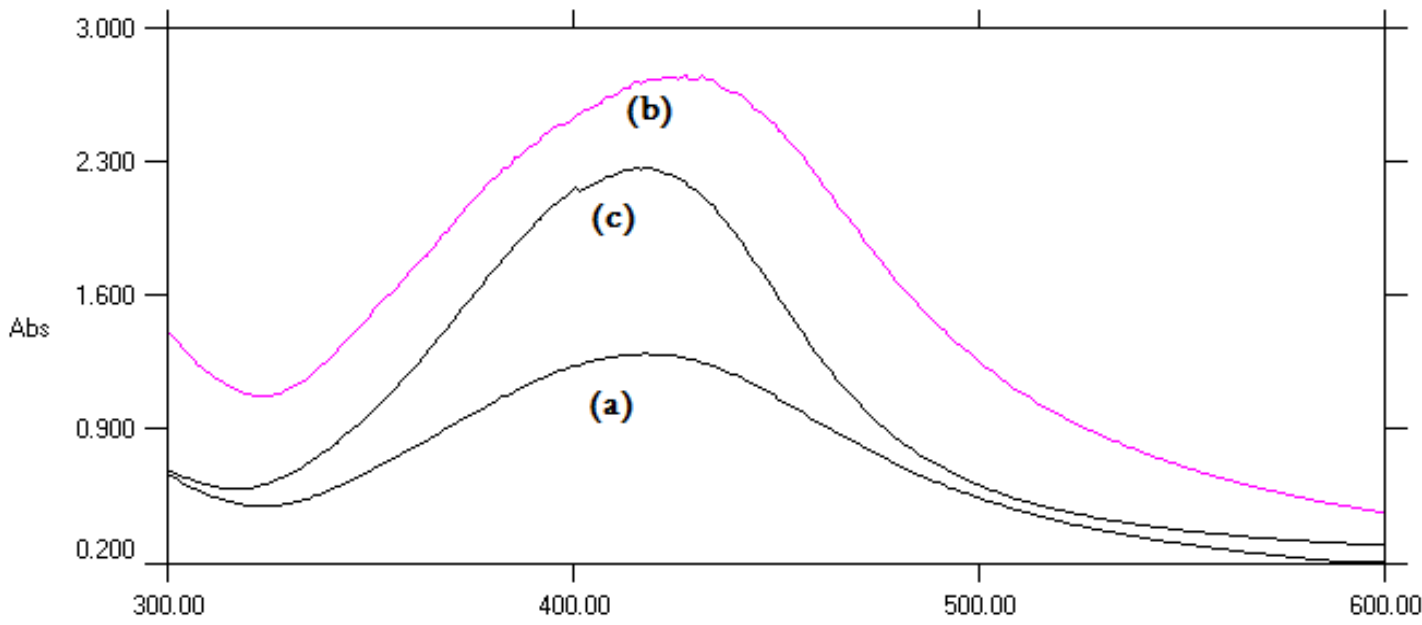

Fig. 3. UV-Vis spectra recorded as a function of biomass concentration of Saccharomyces cerevisiae. 


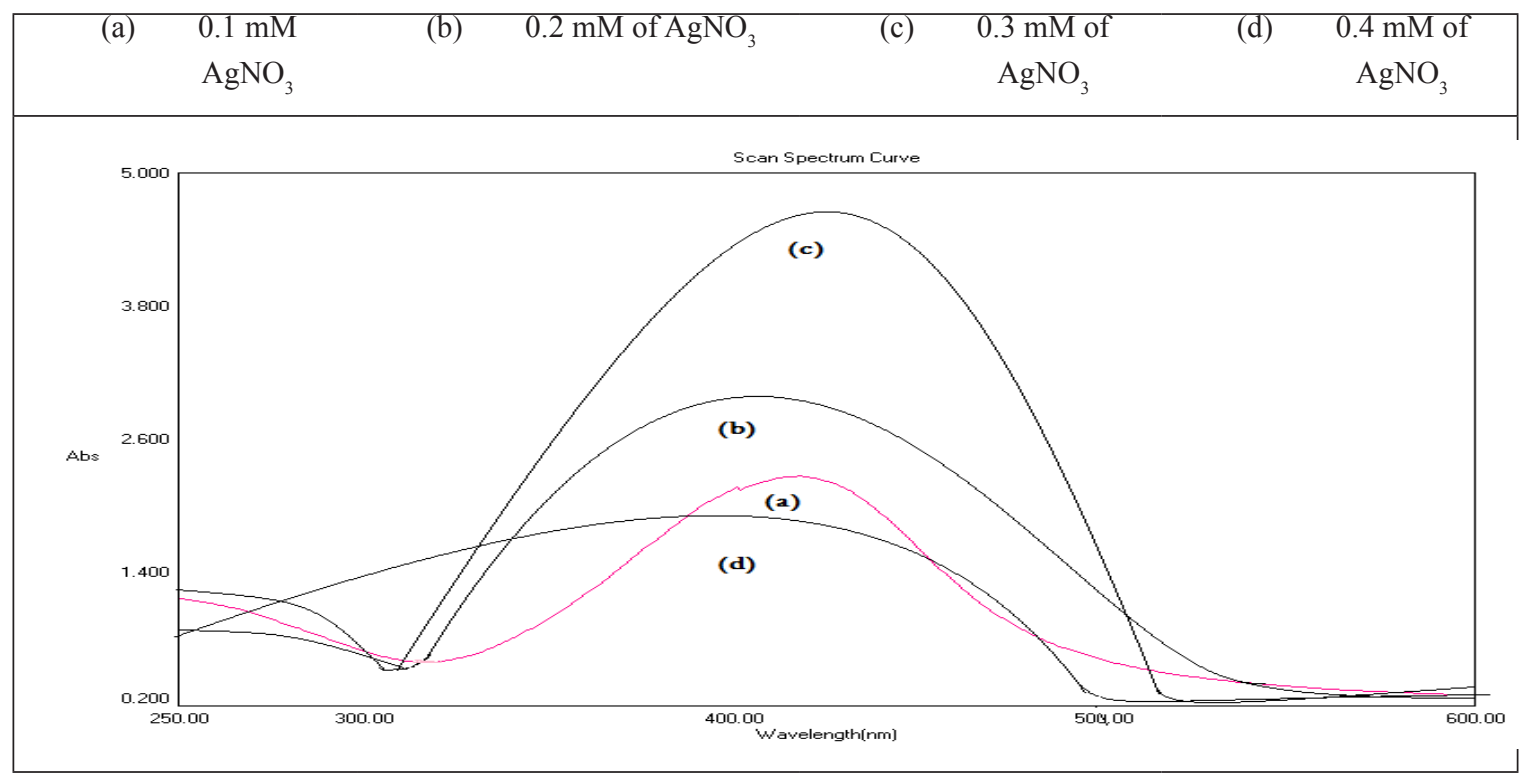

Fig. 4. UV-Vis spectra recorded as a function of silver nitrate concentration for Geotrichum candidum.

Figure (5a and b) showed TEM micrograph and particle size distribution, respectively, using $1.0 \mathrm{~mL}$ of Geotrichum candidum for $72 \mathrm{hr}$ and 0.1 $\mathrm{mM} \mathrm{AgNO}_{3}$. Particle size range was 2.5-13 nm.

Figure (6a and b), showed TEM micrograph and particle size distribution, respectively, using $1 \mathrm{~mL}$ from 7 days old culture of Geotrichum candidum, incubation period was $72 \mathrm{hr}$ and 0.3 $\mathrm{mM} \mathrm{AgNO}$ in the presence of cells. Cells were removed before reaction by $30 \mathrm{~min}$.

Figures ( $6 a$ and $b$ ) showed silver nanoparticles size range 8-30 nm which was obtained by Geotrichum candidum, using $0.3 \mathrm{mM}$ silver nitrate.

Figures 5 and 6 indicated that particle sizes getting bigger with the increase of silver nitrate concentration.

\section{Rhodotorula glutinis}

The effect of silver nitrate concentration on bio-synthesis of silver nanoparticles was studied by exposing $100 \mathrm{~mL}$ of biomass suspension produced from $1 \mathrm{~mL}$ of Rhodotorula glutinis inoculation size incubated on a shaker incubator at $30 \pm 2{ }^{\circ} \mathrm{C}$ and $150 \mathrm{rpm}$ for $72 \mathrm{hr}$ to $0.1,0.2,0.3$, and $0.4 \mathrm{mM}$ of $\mathrm{AgNO}_{3}$ respectively for $24 \mathrm{hr}$.

Figures (7a, b, c and d) represent U.VVis spectra for AgNPs solution prepared by Rhodotorula glutinis by using $0.1,0.2,0.3$, and $0.4 \mathrm{mM}$ of $\mathrm{AgNO}_{3}$ respectively. The best result was obtained by using $0.3 \mathrm{mM}$ of $\mathrm{AgNO}_{3}$.

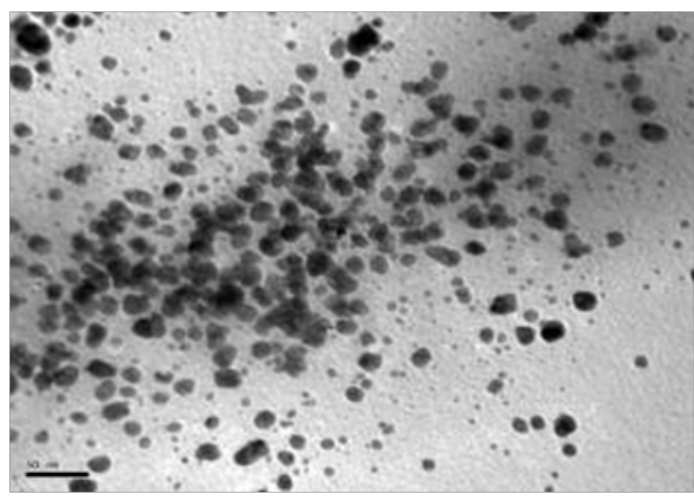

Fig.5a. TEM image of silver nanoparticles formed using $1.0 \mathrm{mM}$ of $\mathrm{AgNO}_{3}$ and $1.0 \mathrm{~mL}$ of Geotrichum candidum.

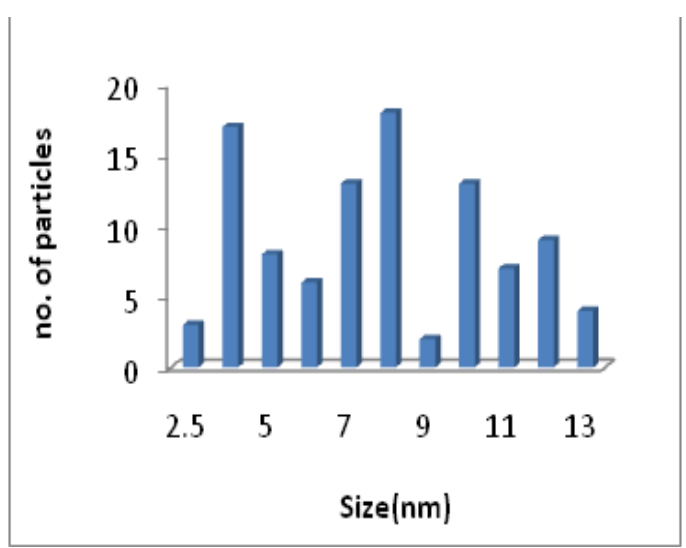

Fig.5b. Histogram illustrating particle size distribution of silver nanoparticles prepared using $1 \mathrm{mM}$ silver nitrate and $1 \mathrm{~mL}$ biomass of Geotrichum candidum. The particles size range is between $2.5 \mathrm{~nm}-13 \mathrm{~nm}$.

Egypt.J.Chem. Special Issue (2017) 


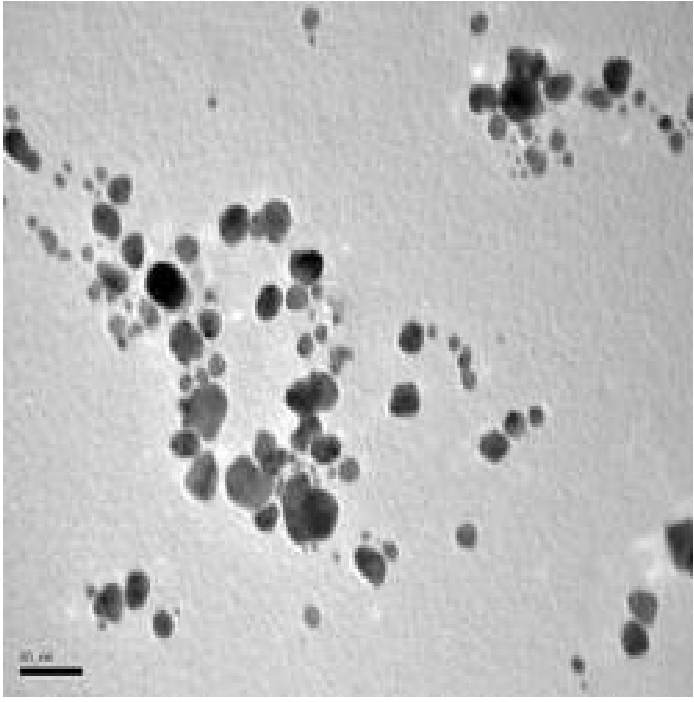

Fig. 6a. TEM image of silver nanoparticles formed using $3.0 \mathrm{mM}$ of $\mathrm{AgNO}_{3}$ and $1.0 \mathrm{~mL}$ of Geotrichum candidum.

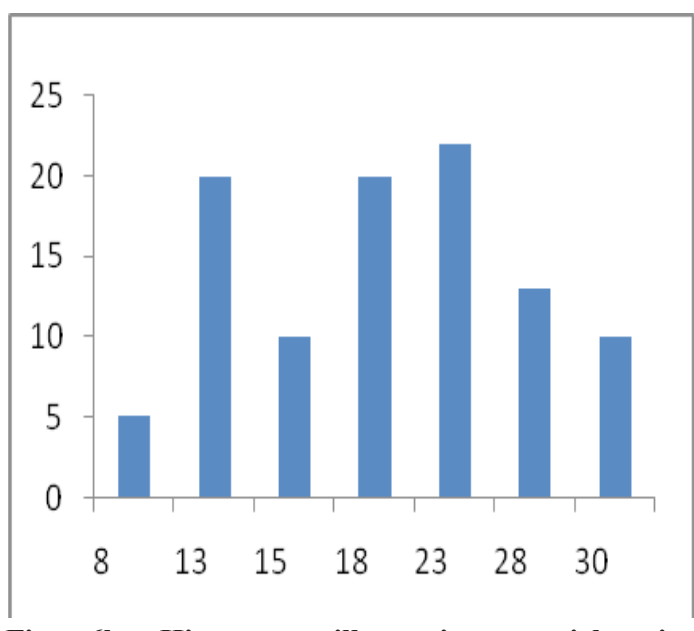

Fig. 6b. Histogram illustrating particle size distribution of silver nanoparticles prepared using $1 \mathrm{mM}$ silver nitrate and 1 mL biomass of Geotrichum candidum. The particles size range is between $2.5 \mathrm{~nm}-13$ nm.

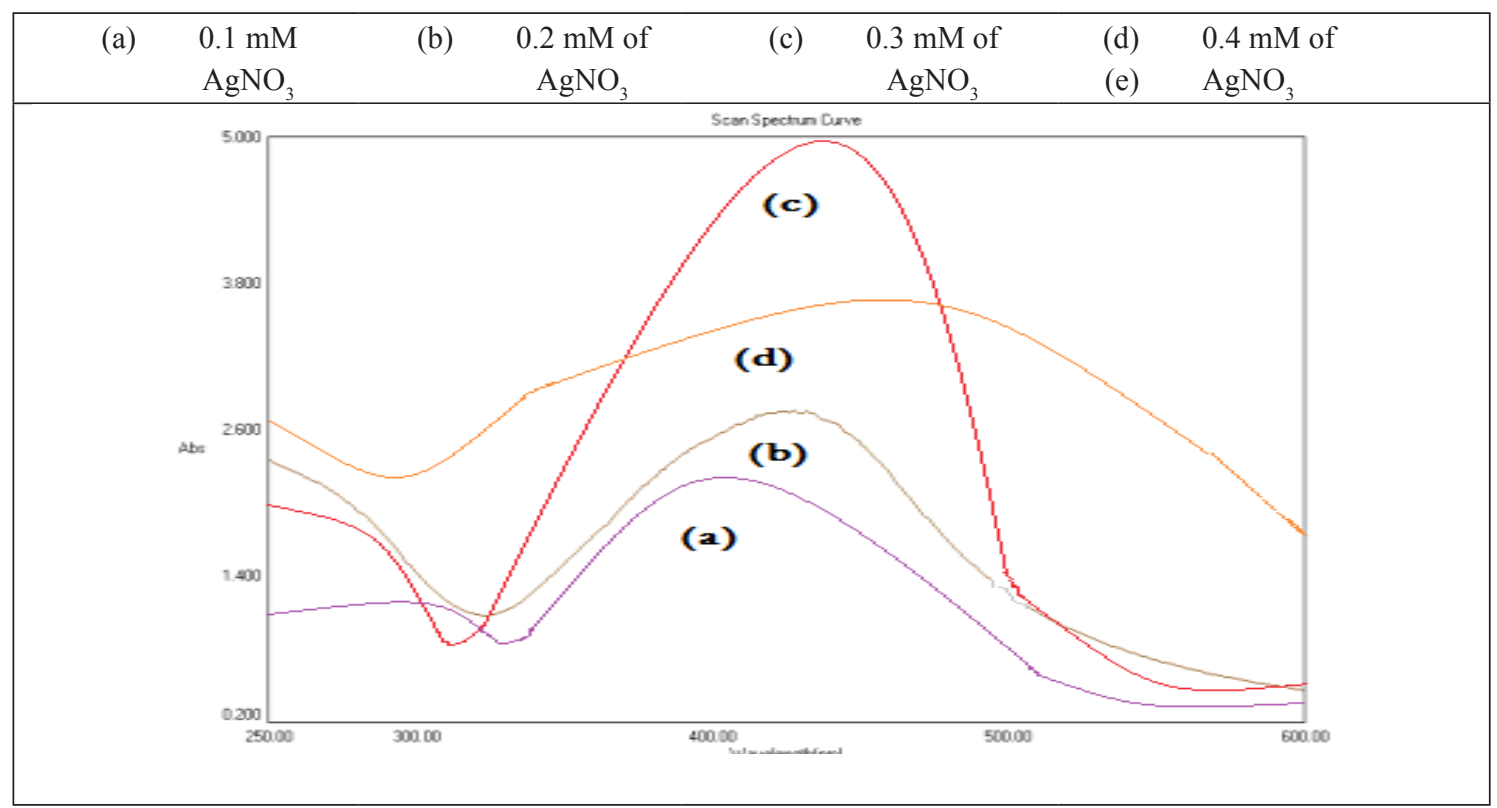

Fig. 7. UV-Vis spectra recorded as a function of silver nitrate concentration for Rhodotorula glutinis.

Figures ( $8 \mathrm{a}$ and $\mathrm{b}$ ) showed TEM micrograph and particle size distribution, respectively, using $1 \mathrm{~mL}$ of Rhodotorula glutinis for $72 \mathrm{hr}$ and $0.1 \mathrm{mM} \mathrm{AgNO}{ }_{3}$. Figures indicated that silver nanoparticles size range 4-14 $\mathrm{nm}$ was obtained by using $0.1 \mathrm{mM}$ silver nitrate concentration.

Figures ( $9 \mathrm{a}$ and $\mathrm{b}$ ) showed TEM micrograph and particle size distribution, respectively, using $1.0 \mathrm{~mL}$ of Rhodotorula glutinis for $72 \mathrm{hr}$, addition of $0.3 \mathrm{mM} \mathrm{AgNO}$. Figures indicated that silver nanoparticles size range $20-50 \mathrm{~nm}$ was obtained by using $0.3 \mathrm{mM}$ silver nitrate concentration.

The particles size range was between $20 \mathrm{~nm}$ $-50 \mathrm{~nm}$. Figures (8 and 9) indicated that particle sizes getting bigger with the increase of silver nitrate concentration. 


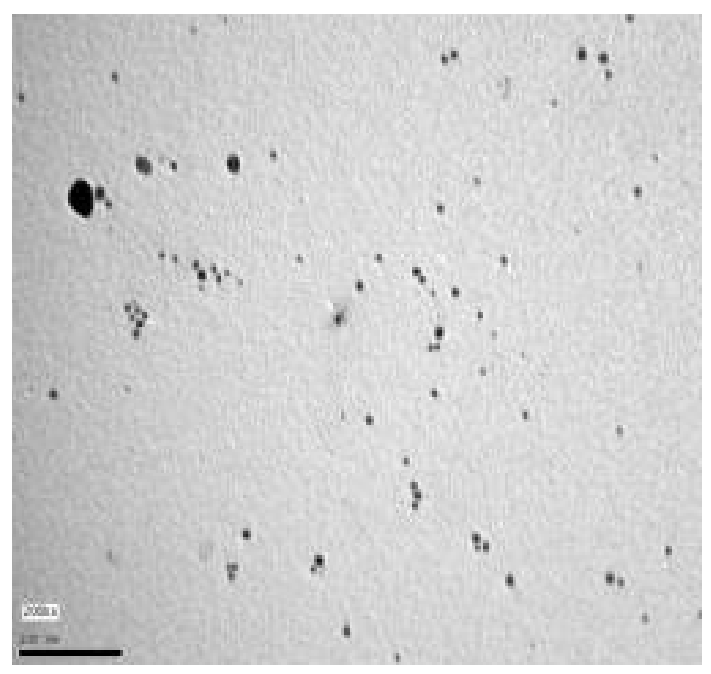

Fig. 8a. TEM image of silver nanoparticles formed using $1 \mathrm{mM}$ of $\mathrm{AgNO}_{3}$ and $1.0 \mathrm{~mL}$ of Rhodotorula glutinis.

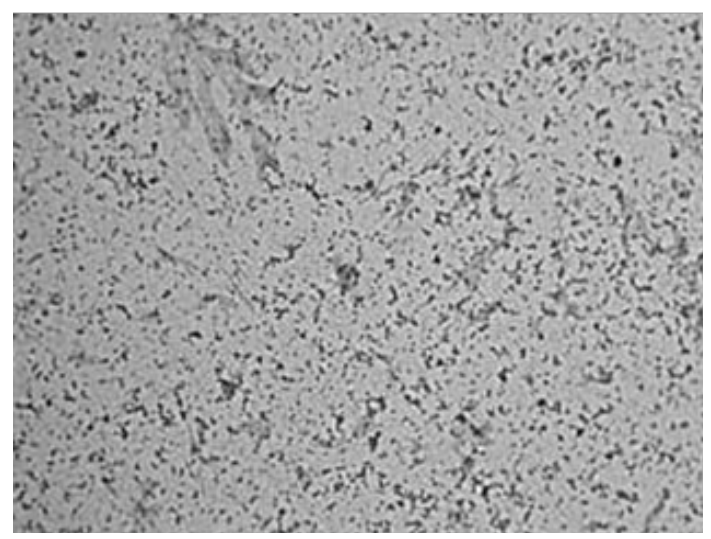

Fig. 9a. TEM image of silver nanoparticles formed using $3 \mathrm{mM}$ of $\mathrm{AgNO}_{3}$ and $1.0 \mathrm{~mL}$ of Rhodotorula glutinis.

\section{Saccharomyces cerevisiae}

The effect of silver nitrate concentration on bio-synthesis of silver nanoparticles was studied by exposing $100 \mathrm{~mL}$ of biomass suspension produced from $1 \mathrm{~mL}$ of Saccharomyces cerevisiae (Baker's yeast) inoculation size incubated on a shaker incubator at $30 \pm 2{ }^{\circ} \mathrm{C}$ at $150 \mathrm{rpm}$ for $72 \mathrm{hr}$ to $0.1,0.2,0.3$, and $0.4 \mathrm{mM}$ of $\mathrm{AgNO}_{3}$ respectively for $24 \mathrm{hr}$.

Figures (10. a, b, c and d) represent U.V-Vis spectra of AgNPs prepared using Saccharomyces cerevisiae by applying $0.1,0.2,0.3$, and $0.4 \mathrm{mM}$ of $\mathrm{AgNO}_{3}$ respectively.

The figures illustrate that the best results obtained for the silver nanoparticles bio-synthesis were by using 0.3.0 $\mathrm{mM}$ of $\mathrm{AgNO}_{3}$.

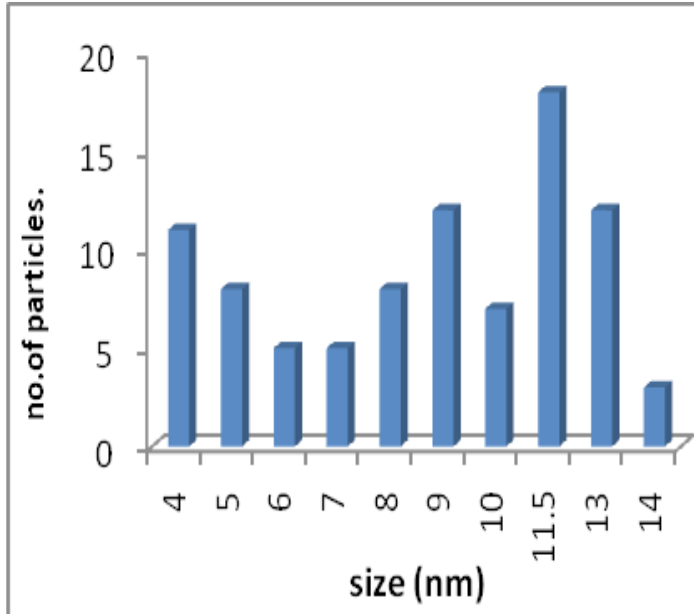

Fig.8b. Histogram illustrating particle size distribution of silver nanoparticles prepared using $3 \mathrm{mM}$ silver nitrate and 1.0 $\mathrm{mL}$ of Rhodotorula glutinis. The particle size range is between $4 \mathrm{~nm}-14 \mathrm{~nm}$.

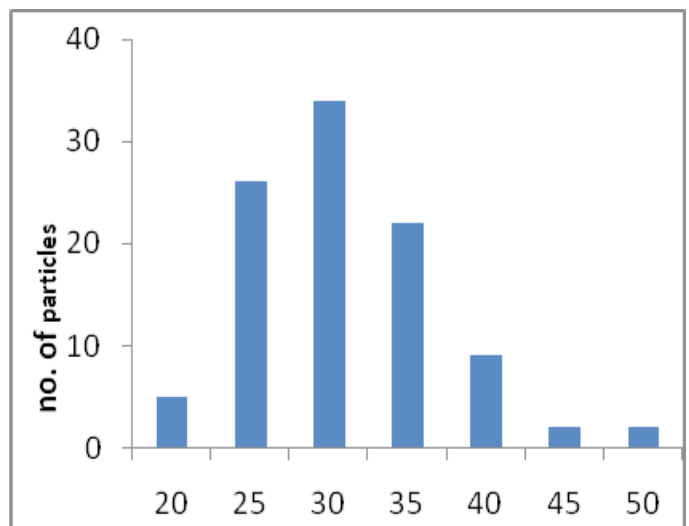

Fig. 9b. Histogram illustrating particle size distribution of silver nanoparticles prepared using $3.0 \mathrm{mM}$ silver nitrate and $1.0 \mathrm{~mL}$ of Rhodotorula glutinis.

Figures (11 a and b) showed TEM micrograph and particle size distribution, respectively, using $1 \mathrm{~mL}$ of Saccharomyces cerevisiae and $0.1 \mathrm{mM} \mathrm{AgNO}_{3}$ incubated for $72 \mathrm{hr}$. Figures (11 $\mathrm{a}$ and $\mathrm{b}$ ) showed that silver nanoparticles size range $1.5-12 \mathrm{~nm}$ was obtained by using $0.1 \mathrm{mM}$ silver nitratelconcentration.

Figures (12 a and b) showed TEM micrograph and particle size distribution, respectively, using $1 \mathrm{~mL}$ of Saccharomyces cerevisiae and $0.3 \mathrm{mM}$ $\mathrm{AgNO}_{3}$ incubated for $72 \mathrm{hr}$.

Figures also showed that silver nanoparticles size range 1-8 nm was obtained by Saccharomyces cerevisiae upon using $0.1 \mathrm{mM}$ silver nitrate. 


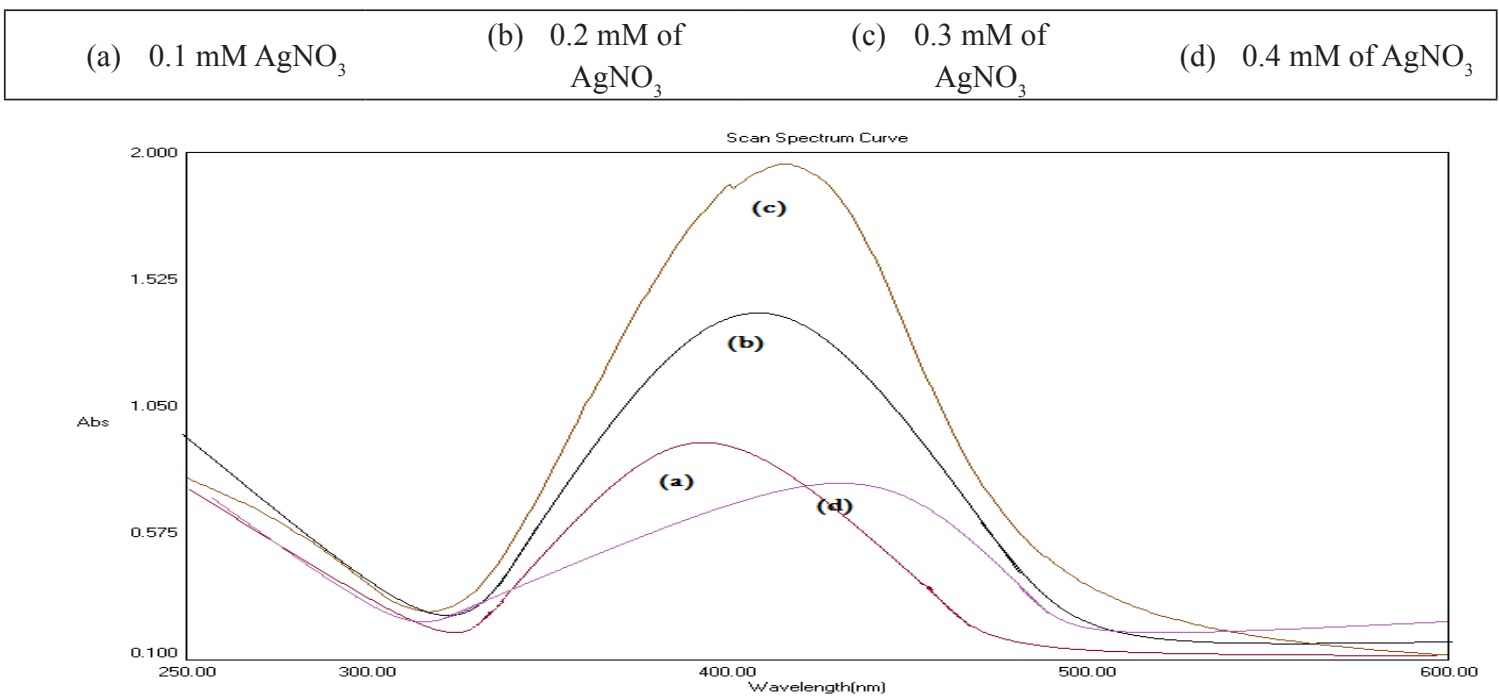

Fig. 10. UV-Vis spectra recorded as a function of silver nitrate concentration for yeast strain Saccharomyces cerevisiae.

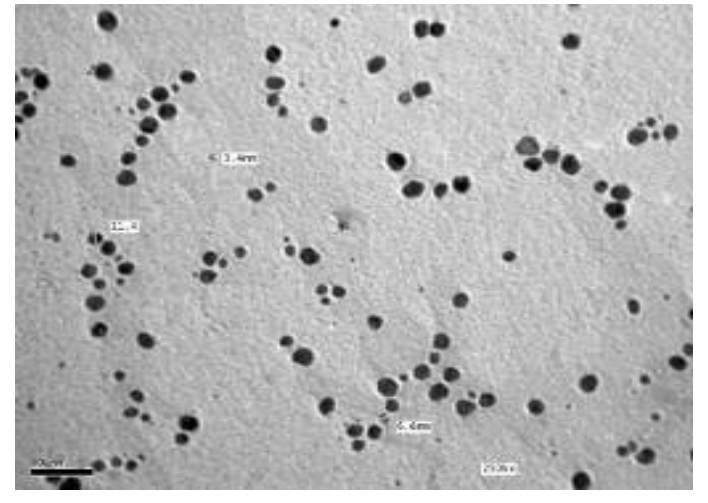

Fig.11a. TEM image of silver nanoparticles formed using $1.0 \mathrm{mM}$ of $\mathrm{AgNO}_{3}$ with $1 \mathrm{~mL}$ biomass for yeast strain Saccharomyces cerevisiae.

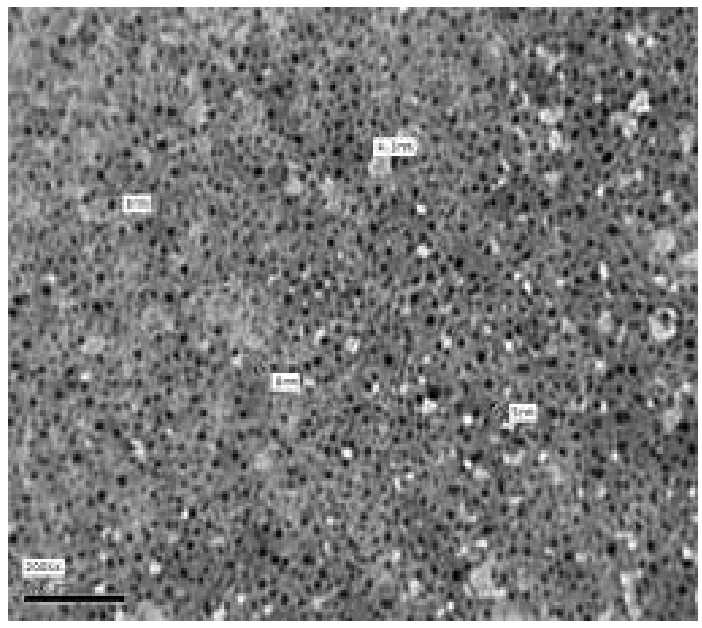

Fig. 12a. TEM image of silver nanoparticles formed using $0.3 \mathrm{mM}$ of $\mathrm{AgNO}_{3}$ with $1 \mathrm{~mL}$ of Saccharomyces cerevisiae.

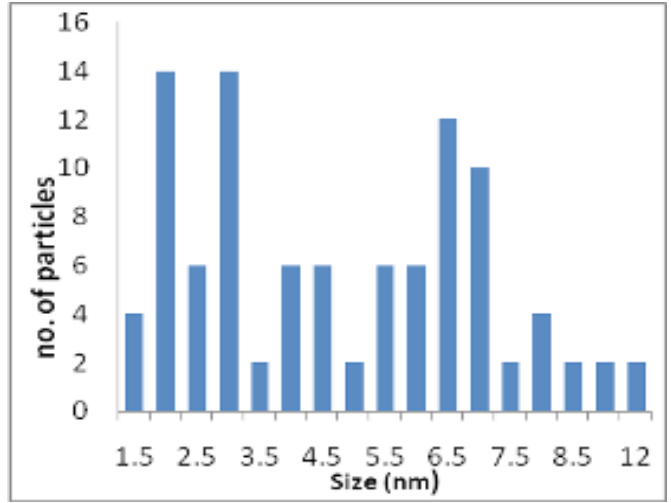

Fig.11b. Histogram illustrating the particle size distribution of silver nanoparticles prepared using $1 \mathrm{mM}$ silver nitrate with $1 \mathrm{~mL}$ biomass of yeast strain Saccharomyces cerevisiae. The particles size range was between $1.5 \mathrm{~nm}-12 \mathrm{~nm}$.

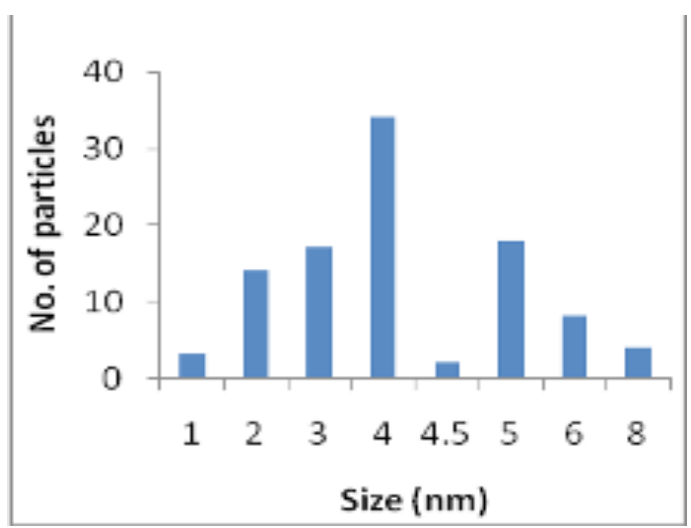

Fig.12b. Histogram illustrating particle size distribution of silver nanoparticles prepared by using 3.0 mM silver nitrate with $1 \mathrm{~mL}$ Saccharomyces cerevisiae. Particles size range is between $1 \mathrm{~nm}$ $-8 \mathrm{~nm}$.

Egypt.J.Chem. Special Issue (2017) 
Figures $(11,12)$ for yeast strain Saccharomyces cerevisiae the particle sizes still in small range with the increase of silver nitrate concentration.

Study of $\mathrm{AgNO}_{3}$ concentration $\mathrm{VS}$ biomass concentration using Saccharomyces cerevisiae

Silver nanoparticles were prepared using the optimum culture conditions for Saccharomyces cerevisiae to prepare different concentrations of $100,300,600$ and $900 \mathrm{ppm}$ of silver nanoparticles.

Different concentrations of silver nanoparticles were obtained by variation in the ratio of yeast inoculum size to silver nitrate concentration. Silver nanoparticles preparation 1:1, 1:3, 2:6

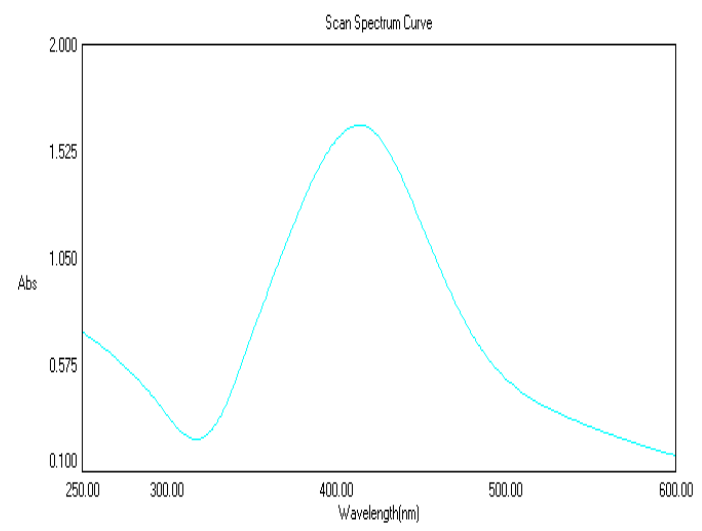

Fig.13a.U.V-Vis spectra for Saccharomyces cerevisiae, the ratio is $1: 1$ (mL inoculum size : $0,1 \mathrm{mM}$ silver nitrate)

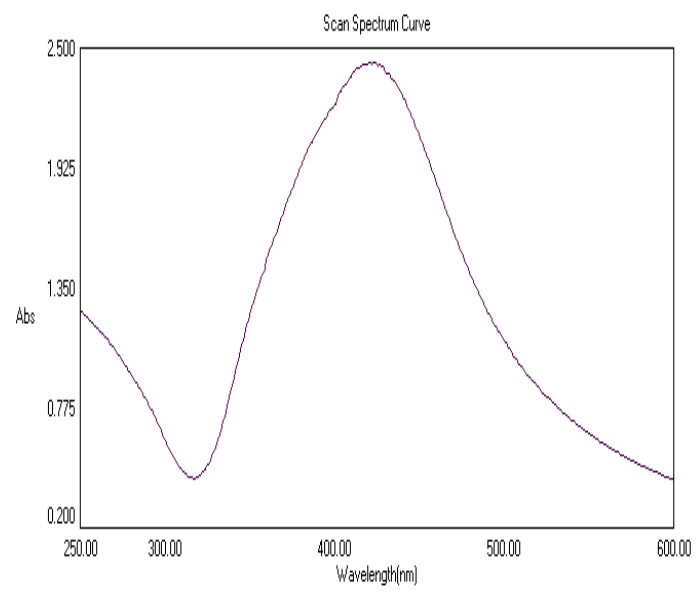

Fig. 13c. U.V-Vis spectra for yeast Saccharomyces cerevisiae. The ratio is $2: 6(2.0 \mathrm{~mL}$ inoculum size : $0.6 \mathrm{mM}$ silver nitrate). and 3:9 (inoculum size : $\mathrm{mM}$ silver nitrate). The previously prepared nano-particles were characterized by UV-Vis spectroscopy and TEM.

Ultra violet-visible (UV-Vis) spectra.

Figures (13. a, b, c and d) represent the U.VVis spectra of AgNPs prepared by Saccharomyces cerevisiae by variation in the ratio of yeast inoculums size to silver nitrate concentration. The ratio was $1: 1,1: 3,2: 6$ and $3: 9$.

Figures (13. a, b, c, d) indicated that silver nanoparticles colloidal solutions prepared using these ratios are feasibly promising for the industrial application.

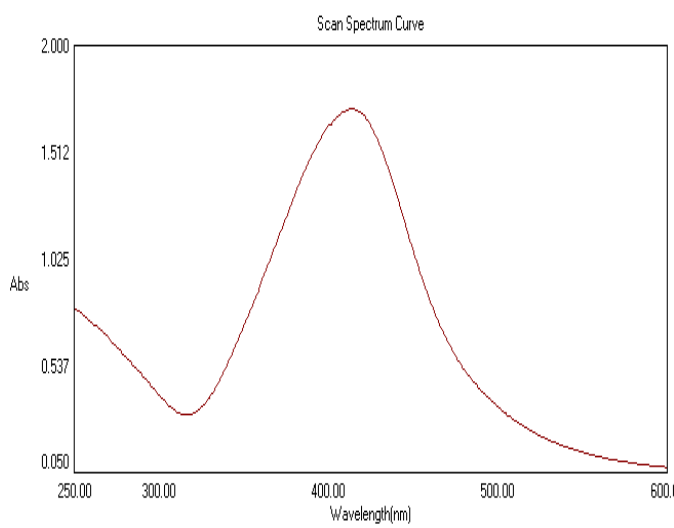

Fig. 13b. U.V-Vis spectra for yeast Saccharomyces cerevisiae. The ratio is $1: 3(1.0 \mathrm{~mL}$ inoculum size : $0.3 \mathrm{mM}$ silver nitrate).

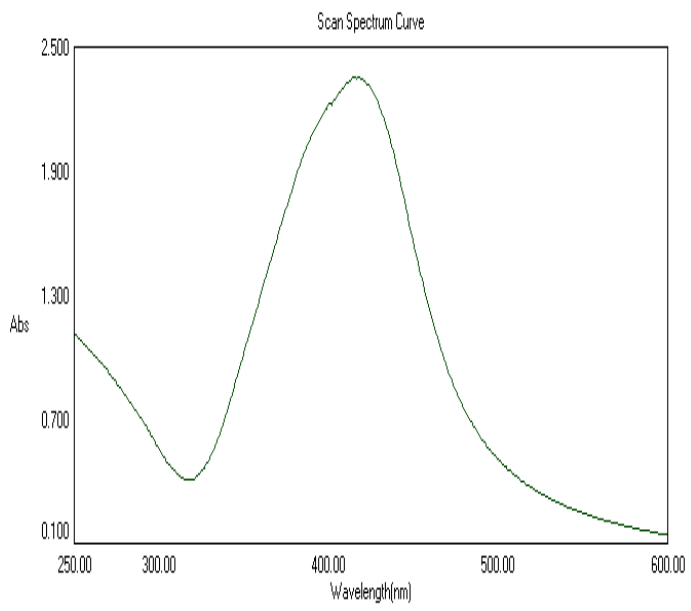

Fig. 13d. The U.V-Vis spectra for yeast Saccharomyces cerevisiae. The ratio is 3:9 (3.0 inoculum size : $0,9 \mathrm{mM}$ silver nitrate). 
Transmission Electron Microscope (TEM)

Figures (14 $\mathrm{a}$ and $\mathrm{b}$ ) showed TEM micrograph and particle size distribution, respectively, using $1 \mathrm{~mL}$ of Saccharomyces cerevisiae and $0.1 \mathrm{mM}$ $\mathrm{AgNO}_{3}$ incubated for $72 \mathrm{hr}$ in the presence of cells. Biomass removed before the reaction done (after $30 \mathrm{~min}$ ).

Figures (14 $\mathrm{a}$ and $\mathrm{b}$ ) showed silver nanoparticle size range 1.5-12 nm obtained by Saccharomyces cerevisiae, using biomass - silver nitrate ratio 1:1 (1.0 mL inoculums : $0.1 \mathrm{mM}$ silver nitrate).

Figures (15 a and b) showed the TEM micrograph and particle size distribution, respectively, also showed silver nanoparticle size range $1-8 \mathrm{~nm}$ prepared by Saccharomyces

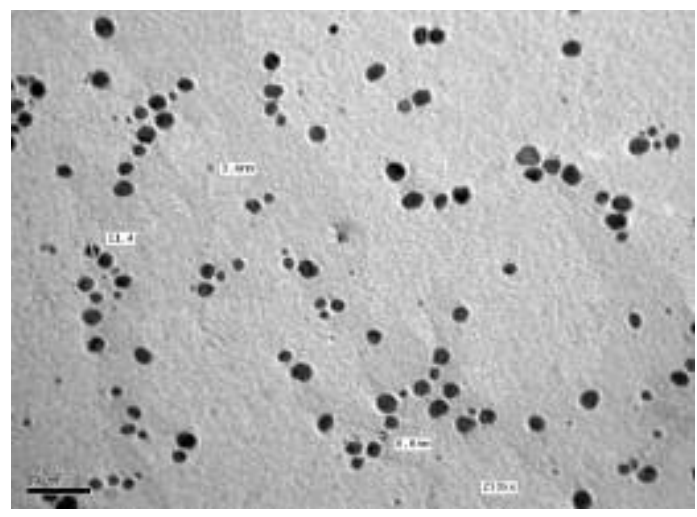

Fig. 14a. TEM image of silver nanoparticles using ratio 1:1 (1.0 $\mathrm{mL}$ inoculums: $0.1 \mathrm{mM}$ silver nitrate).

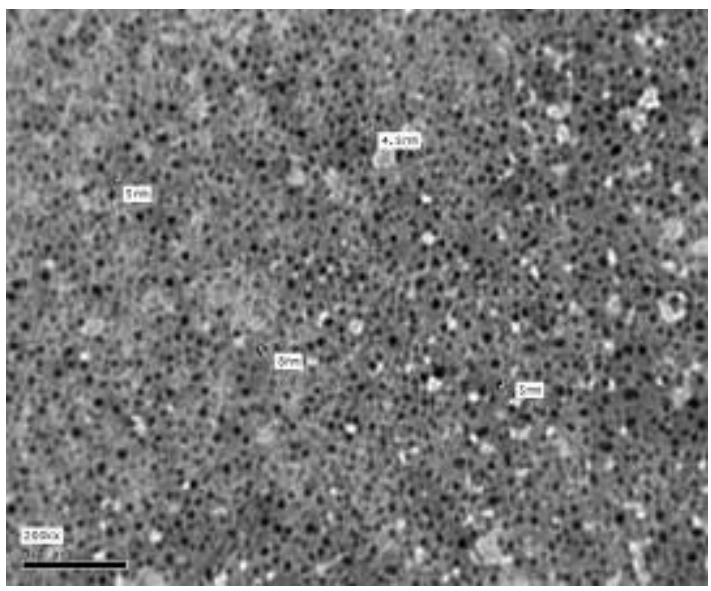

Fig. 15a. TEM image of silver nanoparticles formed using the ratio $1: 3(1.0 \mathrm{~mL}$ inoculums: 0.3 mM silver nitrate).

Egypt.J.Chem. Special Issue (2017) cerevisiae using the ratio $1: 3(1.0 \mathrm{~mL}$ inoculums : $0.3 \mathrm{mM}$ silver nitrate).

Figures (16 $\mathrm{a}$ and $\mathrm{b}$ ) showed t TEM micrograph and particle size distribution, respectively. Also figures illustrate silver nanoparticle size range 1 $-7 \mathrm{~nm}$ which was obtained by Saccharomyces cerevisiae using biomass - silver nitrate ratio 2: 6 (2.0 mL inoculums : $0.6 \mathrm{mM}$ silver nitrate).

Figures (17 $\mathrm{a}$ and $\mathrm{b}$ ) showed TEM micrograph and particle size distribution, respectively. Also illustrate silver nanoparticle size range 2-15 nm which was obtained by Saccharomyces cerevisiae using the ratio $3: 9(3.0 \mathrm{~mL}$ inoculums : $0.9 \mathrm{mM}$ silver nitrate).

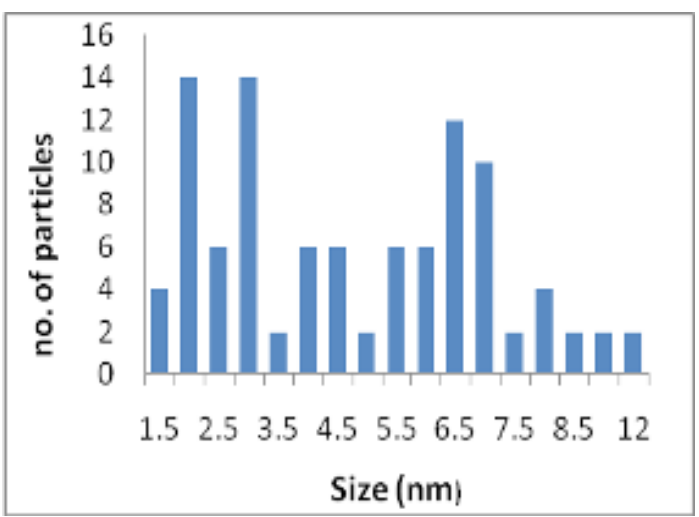

Fig.14b. Histogram showing the particle size and particle size distribution of silver nanoparticles prepared using the ratio 1:1 (1.0 mL inoculums: $0.1 \mathrm{mM}$ silver nitrate). The particles size range is between $1.5 \mathrm{~nm}$ $-12 \mathrm{~nm}$.

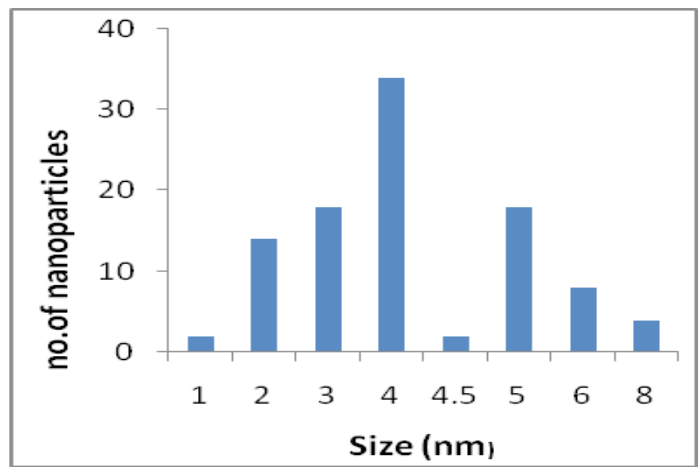

Fig. 15b. Histogram showing the particle size and particle size distribution of silver nanoparticles prepared using the ratio 1: 3 (1.0 $\mathrm{mL}$ inoculums: $0.3 \mathrm{mM}$ silver nitrate). The particles size range is between $1 \mathrm{~nm}-8 \mathrm{~nm}$. 


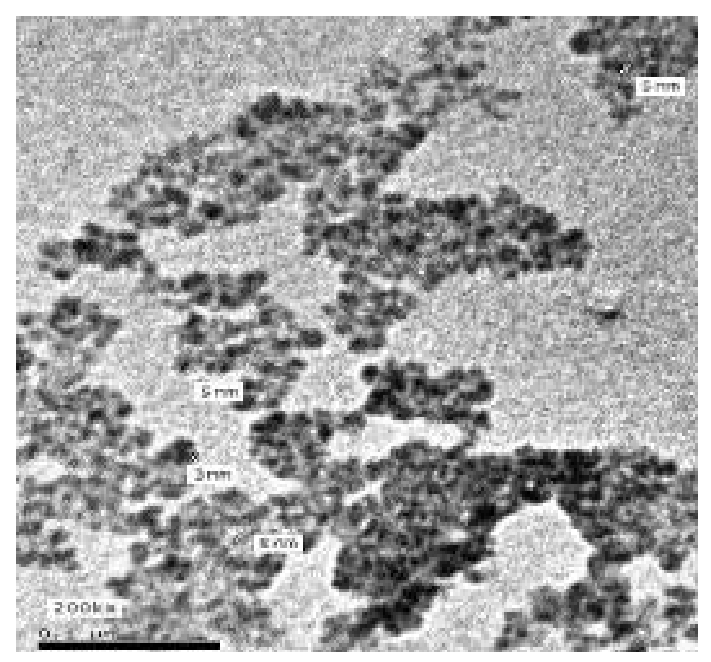

Fig. 16a. TEM image of silver nanoparticles formed using ratio 2: 6 (2.0 $\mathrm{mL}$ inoculums: 0.6 $\mathrm{mM}$ silver nitrate).

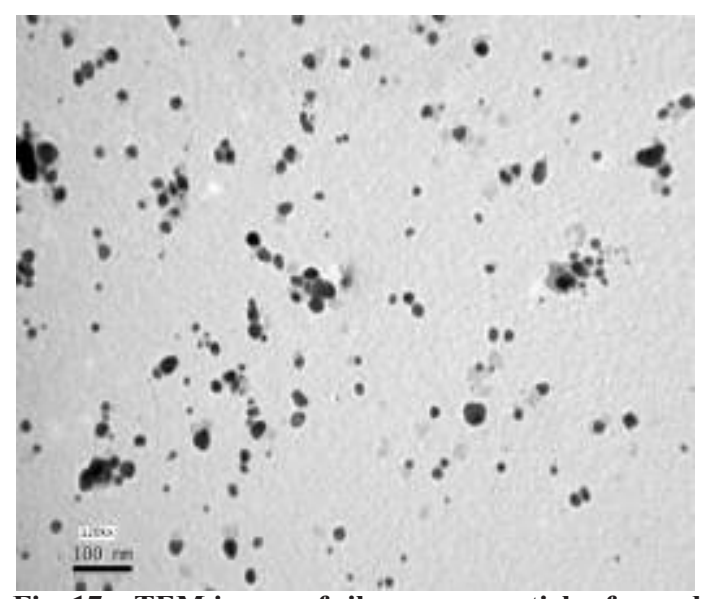

Fig. 17a. TEM image of silver nanoparticles formed using the ratio 3: $9(3.0 \mathrm{~mL}$ inoculums: 0.9 mM silver nitrate).

Application of AgNPs on cellulose based textiles

The so obtained silver nanoparticles as finishing agent were applied to cellulose based textiles [16]. Final evaluation of physical and antimicrobial properties of the treated fabrics was performed. Cotton fabrics and cotton/polyester blend fabrics having excellent antibacterial properties and can withstand repeated washing, could be obtained by treating the fabrics with 50 ppm AgNPs in the presence of binder $[17,18]$.

Antimicrobial activity was observed when silver nanoparticles were incorporated in cotton and cotton/polyester fabrics. This work demonstrates the possible use of bio-

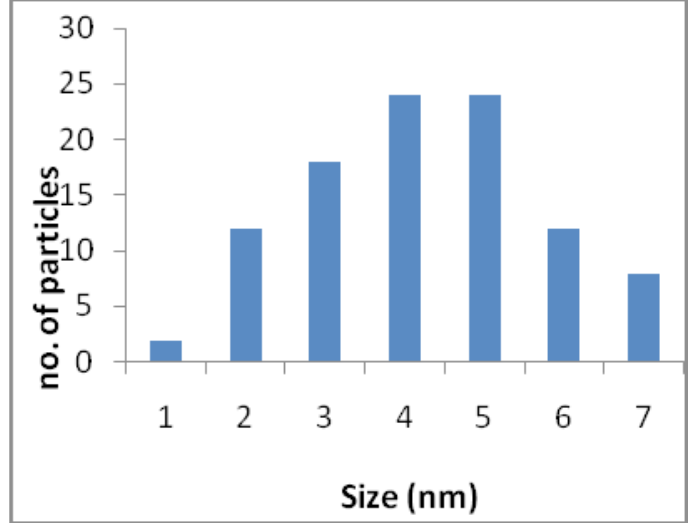

Fig.16b. Histogram showing the particle size and particle size distribution of silver nanoparticles prepared using ratio 2: 6 (2.0 mL inoculums: 0.6 mM silver nitrate). The particles size range is between $1 \mathrm{~nm}$ $7 \mathrm{~nm}$.

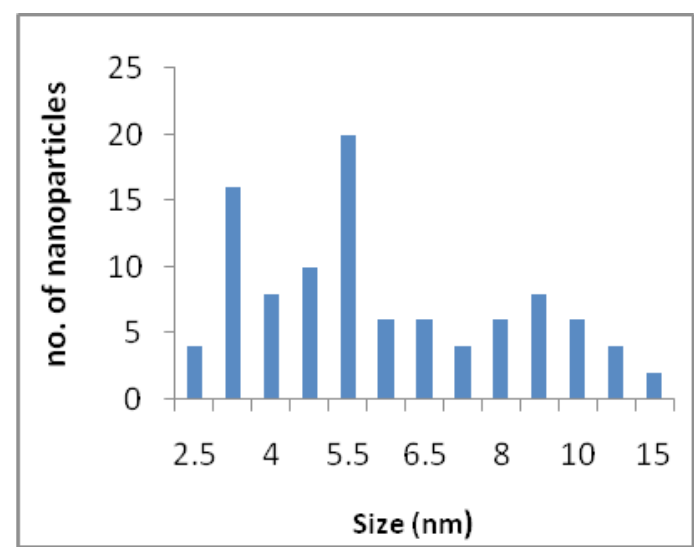

Fig. 17b. Histogram showing the particle size and particle size distribution of silver nanoparticles prepared using The particles size range is between $2.5 \mathrm{~nm}$ $15 \mathrm{~nm}$.

logical synthesized silver nanoparticles and its incorporation in fabrics impart to sterilization of fabrics $[17,19]$.

\section{Conclusion}

Saccharomyces cerevisiae, Rhodotorula glutinis and Geotrichum candidum were tested for biosynthesis of silver nanoparticles (AgNPs). Factors affecting biosynthesis of AgNPs for industrial application were studied.

The maximum concentration of well stabilized AgNPs obtained was 900 ppm with a mean diameter range of 1.5-12 $\mathrm{nm}$ by Saccharomyces cerevisiae. 


\section{References}

1. Whitesides G.M., Theright size in nanobiotechnology. Nature Biotechnol., 21, 1161-1165. (2003).

2. Morons J.R., Elechiguerra J.L. and CamachoBragado A., GAO X. and Lara Yacaman H.M.J., Interaction of silver nanoparticles with HIV: 1. Journal of Nanobiotechnol. 3, 6-15 (2005).

3. Fouda A.M.R., Mohamed A.A., Mamdoh S. Elgamal, Saad EL-Din Hassan, Salem, S. Salem and Tharwat I Shaheen, facile approach towards medical textiles via myco-synthesis of silver nanoparticles. Der Pharma Chemica, 9(13), 11-18, (2017).

4. Klaus T., Joerger R. Olsson E. and Granqvist C.G. Silver- based crystalline nanoparticles, microbially fabricated. Proceeding National Academy of Science USA 96, 13611-13614 (1999).

5. Bhattacharya D. and Gupta R., Nanotechnology and potential of microorganisms. Crit. Rev. in Biotechnol. 25, 199-204 (2005).

6. Mukherjee P., Ahmad A. Mandal D. and Senapati S. Fungus mediated synthesis of silver nanoparticles and their immobilization in the mycellial matrix. A novel biological approach to nano particle synthesis. Nano Lett. 1, 515-519 (2001).

7. Sastry M.M., Ahmad A. and khan. I., Biosynthesis of metal nanoparticles using fungi and actinomycete. Curr. Sci. 85, 202-206. (2003).

8. Mohamed A. A., Hassan S., Fouda A., Elgamal M. S. and Salem S. S., Extracellular biosynthesis of silver nanoparticles using Aspergillus sp. and evaluation of their antibacterial and cytotoxicity. Journal of Applied Life Sciences International. 11(2), 1-12 (2017).

9. Nelson D., Priscyla D.M., Oswald L.A., Gabriel D.H., D' Souza and Eliza E., Mechanistic aspect of biosynthesis of silver nano-particles by several Fusarium oxysporum. J. Nanobiotechnol. 3 (2005).

10. Asem A. Mohmed, Saad EL-Din Hassan, Amr Fouda, Mamdouh S. Elgamal and Salem S. Salem, extracellular biosynthesis of silver nanoparticles using Aspergillus sp. and evaluation of their antibacterial and cytotoxicity. JALSI, 11(2), 1-12 (2017).

11. Hamedi A., Vahid H. and Ghanati F., Optimization of the medium composition for production of mycellial biomass and exopolysaccharide by Agaricus blazei Murill DPPh 131. Biotechnology 6(4), 456464 (2007).

Egypt.J.Chem. Special Issue (2017)
12. Mao X.B., Eksriwong T. Chuvatcharian S. and Zong J.J., Optimization of carbon source and carbon/nitrogen ratio for cordycepin production by submerged cultivation of medicinal mushroom Cordycep militaris. Process Biochemistry 40,16671672 (2005).

13. Cui F.J., Li. Y. Xu H.Y. and Tao K., Optimization of the medium composition for the production of mycellial biomass and exo-polymer by Grifola frondosa GF9801 using response surface. Methodology 97,1209-1216 (2006).

14. Mur,at, E. Optimization of medium composition for actinorhodine production by Streptomyces coelicolor A3 (2) with response surface methodology. Process Biochemistry 39, 1057-1062 (2004).

15. Kumar S., Kazemian M. Gozavi W. Kulkarini K. Pasrica R. and Ahmad A., Nitrate reductasemediated synthesis of silver nanoparticles from AgNO3. Biotechnol Lett 29, 439-445 (2007).

16. Zahran M.K. Asem A. Mohamed, Mohamed F.M., and El-Rafie, M.H., Utilization of silver nanoparticles synthesized by biological process for preparation of antimicrobially finished cotton and cotton/polyester fabrics. 20 $0^{\text {th }}$ International Conference, Structure and Structural Mechanics of Textiles, 195-200. (2014).

17. El-Rafie M.H., Mohamed A.A., Shaheen Th.I. and Hebeish A., Antimicrobial effect of silver nanoparticles produced by fungal process on cotton fabrics. Carbohydrate Polymers 80, 779-782 (2010)

18. El-Rafie M. H., Mohamed A. A., Shaheen Th. I. and Hebeish A., Investigation into the bio-synthesis of silver nanoparticles using fungi secreted enzymes and proteins, Part II: Extracellular synthesis of silver nanoparticles induced by Penicillium roquefortii and Fusarium solani. Egypt, J. Text. Polym. Sci. Technol. 14(1), 53-64 (2010).

19. El-Rafie M.H., Shaheen Th.I., Mohamed A.A. and Hebeish A., Bio-synthesis and applications of silver nanoparticles onto cotton fabrics. Carbohydrate Polymers, 90(2), 915-920, 1 October (2012).

(Received 11/9/2017; accepted $23 / 11 / 2017$ ) 
التخليق الحيوى لجسيمات الفضة النانوية القابلة للتطبيق الصناعي باستخدام إنزيمات وبروتينات الخمائر الفظرية

عاصم عبد الموجود محمد1، مجدى زهران² و محمد حسين الرافعى 3

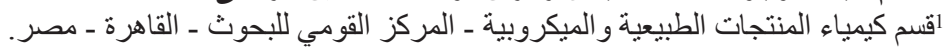

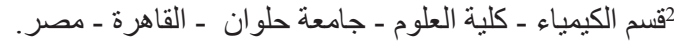

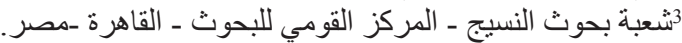

تم اختيار قدرة الخمائر سكروميسز سيريفيسياب، رودوتورولا غلوتينيس و جيوتريتشوم كانديدوم على التخليق

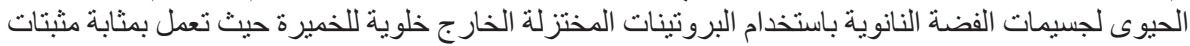

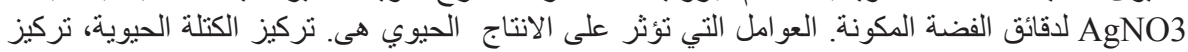

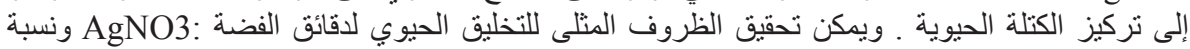

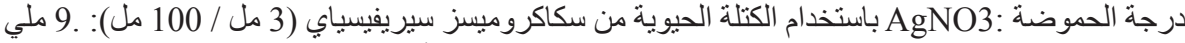

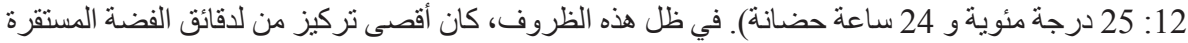
جيدا تم الحصول عليها 900 جزء في المليون مع منوسط قطر ها من 12-1.5 نانو منر ـ و هذايمثل تركيز ا مناسبا بالنسبة للتطبيقات الصناعية. 